\section{OPEN ACCESS \\ Education \\ sciences}

ISSN 2227-7102

www.mdpi.com/journal/education

Article

\title{
A Non-Formal Student Laboratory as a Place for Innovation in Education for Sustainability for All Students
}

\author{
Fiona Affeldt ${ }^{\dagger}, *$, Katharina Weitz ${ }^{\dagger}$, Antje Siol ${ }^{\dagger}$, Silvija Markic ${ }^{\dagger}$ and Ingo Eilks $^{\dagger}$ \\ Department of Biology and Chemistry, Institute for Science Education (IDN) - Chemistry Education, \\ University of Bremen, Leobener Str. NW2, Bremen 28334, Germany; \\ E-Mails: katharina.weitz@uni-bremen.de (K.W.); asiol@uni-bremen.de (A.S.); \\ smarkic@uni-bremen.de (S.M.); ingo.eilks@uni-bremen.de (I.E.)
}

$\dagger$ These authors contributed equally to this work.

* Author to whom correspondence should be addressed; E-Mail: faffeldt@uni-bremen.de;

Tel.: +49-421-218-63287.

Academic Editor: Erin Frisk Redman

Received: 30 June 2015 / Accepted: 11 September 2015 / Published: 21 September 2015

\begin{abstract}
In many Western countries, non-formal education has become increasingly recognized as a valuable addition to the traditional educational system. In recent years, a special form of non-formal student laboratories (Schülerlabor) has emerged in Germany to promote primary and secondary practical science learning. This paper describes a developmental project on Schülerlabor learning environments for all students with a particular focus on sustainability education in the context of chemistry-related topics. The goal of reaching all students puts intentional pressure on the development process of learning environments. It forces the Schülerlabors to create a detailed model of differentiation, which can reach all learners of different interests and abilities. This also includes low-achievers and students who have disadvantaged educational biographies. In this sense, the structuring of non-formal learning environments simultaneously becomes a process of innovation with respect to both the curriculum and the teaching methods. In this paper, we present a corresponding model of differentiation and a specific example focusing on the learning about protecting and preserving metal objects in science education. Preliminary results and implications from the accompanying evaluation are also discussed.
\end{abstract}


Keywords: non-formal education; education for sustainability; chemistry education; innovation; curriculum; differentiation

\section{Introduction}

In many Western countries, non-formal education has become a recognized pillar of the educational system [1]. In Germany, a special form of non-formal student laboratories has emerged in recent years to promote primary and secondary science education, the so-called Schülerlabor [2]. The name "Schülerlabor" can be translated as student laboratory (SL). The word "Schüler" in German refers to school pupils exclusively, not to university students [3]. More than 300 such laboratories exist all over Germany. Most are connected to universities, larger research institutes and industrial plants [2]. However, every laboratory has a specific focus, thus not every science domain is presently available in every regional environment.

SLs were founded originally in universities for motivational purposes to overcome a shortage in young people embarking into academic careers in science and engineering. Thus, the SLs in the beginning were mainly focusing on older and higher achieving students. Over time, the idea of the SL adapted into a broader movement to support science learning on a more general level by offering students of all schooling levels out-of-school experiences and practical lab work which has been challenging to implement in traditional schools due to a lack of equipment, time, finances, or overall quality in the school lab facilities [2]. The rationale behind this educational innovation was to promote science learning and to improve students' engagement in science and engineering studies [4]. Typically, SL visits are half- or full-day excursions to well-equipped laboratories, where practical lessons take place. Visits to the SL are, in most cases, compulsory for all students, since the teacher decides to visit the SL as an officially-sponsored school event. In many cases, the activities in the SL follow a prescribed structure. The laboratory visit is not always directly connected to the school curriculum. Quite often student teachers take part in supervising the school students as part of their teacher training program making the SL also a place for pre-service teacher education $[2,3]$.

Previous studies demonstrate that SL visits have great potential for achieving positive short- and medium-term effects with regard to levels of personal interest and motivation [5]. Itzek-Greulich et al. [6] have demonstrated that SLs can also lead to improvements in cognitive achievement. Both Itzek-Greulich et al., and Zehren, Neber and Hempelmann [7] have concluded that repeated visits to the SL, especially when adapted to formal learning in school, have more long-term potential for creating positive effects in terms of motivation and achievement.

This paper reports on an initiative of developing SL learning environments in a network of four German universities. This network intends to promote sustainability education for all students via the SL. The SLs involved implement an innovative model of differentiation which intends to include all learners. The program specifically aims to also provide low-achievers and students with disadvantaged educational biographies an environment for learning both about and for sustainability in the context of chemistry-related topics. At the same time, the project aims at curriculum innovation and continuous professional development for teachers. One example covering the protection and preservation of metal 
objects is presented here for illustration. Preliminary results and implications from the accompanying evaluation are also discussed.

\section{Background}

\subsection{Non-Formal Chemistry Student Laboratories as Places for Learning and Innovation}

In 2012, the OECD (Organization for Economic Co-operation and Development) [8] defined informal learning as out-of-school learning which is unstructured and does not follow a specific curriculum. Examples include both individual visits to a museum, a zoo, or a science exhibit, but also the consumption of science programs on TV and the reading of science articles found in public media. Also non-formal learning occurs out of the traditional school environment. However, non-formal learning tends to have a specific structure and is often connected to various types of prescribed programs or curricula [9]. Informal and non-formal learning in science education follow a broad range of goals and offer learners various settings [3]. Such settings range from unstructured environmental field trips or informal visits to industry and business settings to specific non-formal learning programs offered by museums, zoos, botanical gardens, science centers, or science departments at universities. They can also encompass extra-curricular science lessons offered either on or off the school campus [1,9]. Coll et al. [9] point out that informal and non-formal learning, although officially defined and widely used, are often incoherently applied. This creates confusion. Quite frequently both terms are indiscriminately used to describe any kind of school event which takes place outside of school and/or outside the regular curriculum. Learning experiences outside the school campus clearly belong to the informal or non-formal sectors, although sometimes the activity undertaken is directly connected to the school science curriculum and student participation is obligatory. With non-obligatory courses in school the situation becomes a bit more difficult. Generally these offerings belong to the formal sector. However, due to the fact that they are non-compulsory and not always structured by a specific curriculum, they may contain quite a lot of non-formal character.

Using two examples from Ireland and Germany, Garner, Hayes and Eilks [3] recently discussed the potential which non-formal educational initiatives have with respect to curriculum development and innovation in science education. They pointed out the fact that the greater freedom and flexibility available in non-formal education allows for the development and testing of new teaching and learning scenarios. This includes the incorporation of extremely current topics into the science curriculum. Garner, Siol and Eilks [10] have already described a project in which innovations clearly focused on sustainability issues selected from the domains of chemistry and chemical technology for their use in the SL. The authors implemented their learning environments embedded in several sustainability topics directly connected to formal learning in school in the SL, with a given, but adaptable, structure and taking place outside school giving the SL activities the character of non-formal education. Their project showed promising indications of a rise in student motivation. They also found useful contributions to curriculum innovation and ideas for continuous professional development for teachers in the field of education for sustainability. Via the SL environments teachers learned about new content and current developments in chemistry, e.g., issues of green chemistry and sustainable technologies. They also learned about innovative pedagogies, e.g., models of inquiry-based science 
learning, and new experiments that were developed in the non-formal learning environments. The teachers were able to follow them and in the same time experienced how their students reacted to them. SLs also offer situations where teachers can support their students individually, thereby developing personal views of themselves and their students. Teachers improve both their content knowledge and pedagogical content knowledge, and learned how new experiments and experimental techniques can be effectively carried out in educational settings.

\subsection{Education for Sustainability in Non-Formal Chemistry Student Laboratories}

The idea of sustainable development was defined in the 1970s and 1980s as "development that meets the needs of the present without compromising the ability of future generations to meet their own needs" [11] (p. 11). Since then sustainability and sustainable development have become normative, guiding principles of the international community, the world economy, global civil society, and politics [12]. According to Agenda 21, sustainable development encompasses a balanced view of ecological, economic, and socio-cultural issues. Education was identified as a key domain for realizing sustainable development [13]. Agenda 21 also raised the idea of Education for Sustainable Development (ESD). ESD was suggested as a tool for preparing younger generations to become responsible citizens, who can participate in a democratic society to shape it for a sustainable future. This concept was then further refined in general terms and for chemistry education in particular [12].

Without a doubt chemistry education is one field that can be used to promote ESD [12]. Chemistry and the chemical processes have been responsible for many previous non-sustainable developments, which contributed to high levels of resources consumption and rising environmental problems in the past [14]. One example is the chemistry of plastics, e.g., PVC, which is under controversy since growing waste and environmental problems are associated with the broad use of so many plastics [15]. Today one of the central aims of modern chemistry is to reduce emissions, waste production, the consumption of raw materials, and energy usage. In times of increasing scarcity of many resources for chemical production, resources need to be used efficiently. The chemical industry, research groups, and their corresponding scientific societies worldwide have developed frameworks to fulfill this responsibility [16]. The most prominent framework is green chemistry suggested in the 1990s in the USA. Green chemistry here is understood as "the utilization of a set of principles that reduces or eliminates the use or generation of hazardous substances in design, manufacture and application of chemical products" [17] (p. 8). Green and sustainable chemistry have become guiding frameworks for contemporary chemistry research, development, and industrial production worldwide [18]. Accordingly, innovations in chemistry education have a special responsibility to address the corresponding issues in teaching [19].

Keeping in mind that the main ideas of sustainable and green chemistry only emerged about 20 years ago and that many of the technologies in corresponding fields are still under development, it is understandable that teaching materials still are in short supply [20]. Teachers' education also seems to lack sufficient measures to prepare in the field of education for sustainability [21]. Generally, adoption of innovations in school are often extremely slow and lack both sufficient support mechanisms and recognition of the importance of teachers' underlying beliefs, attitudes and knowledge [22]. This is also the case for implementing ESD into chemistry education [20]. Thus, education for sustainability 
might be considered as a valuable field for SL activities. SLs can aid in the fast transfer of new topics and pedagogies into teaching practices, while at the same time bettering the chances of non-formal learning environments to aid in curriculum innovation and continuous professional development among teachers [3]. The authors' own experiences in a recent project called "Sustainability and Chemistry in the Non-formal Student Laboratory" support this perspective [10,23]. In this project two German SLs developed and implemented learning environments over a time period of three years. The accompanying studies revealed the potential for curriculum innovation, raising student motivation and fostering content learning. It also contributes to pre- and in-service teachers' professional development [24].

\subsection{A Model for Learning in Non-Formal Chemistry Student Laboratories for All Students}

Among other things, non-formal education in the SL aims to motivate students to continue their studies in science and engineering [4]. Therefore, in recent years many corresponding learning environments have been established at German universities, which originally targeted mainly upper secondary science students and high-achievers. The idea was to motivate such pupils to embark on university studies in the science and engineering fields [25]. However, a focus on this group might overlook important opportunities of SLs to extend science education for all students, e.g., in the field of education for sustainability [26]. Environmental attitudes and acceptance of sustainability thinking tend to be quite developed among more mature, higher-achieving students, especially those with advanced educational backgrounds (e.g., based on a high socio-economic status and academic background of their parents). The exact opposite is the case for many students with less-advanced educational biographies. These learners often come from an environment characterized by a lower socio-economic status, a migration background of either the student or their parents, and linguistic problems. Often lower educational achievement in the sciences and less well-developed attitudes towards environmental stewardship, including knowledge and skills in questions of sustainability, have been found in this group of students [26].

Education for sustainability among students with less advanced educational biographies presents new challenges, since these students also have problems with general school achievement in many cases [26]. To address these challenges, a project was begun which uses SLs to offer all students, either with a more advanced educational background or with a disadvantaged educational biography, the chance of developing their knowledge and skills concerning sustainability issues. These SLs relate learning for sustainability to chemistry-specific content, so that pupils can understand and participate in corresponding socio-scientific discussions. This also should allow them to make educated choices regarding whether professions in science and technology make sense for their future plans. Thus, one central pedagogical innovation in the present project is a detailed system of differentiation. The differentiation model takes into account students' diversity in their personal interests, cognitive achievements, problem-solving skills, and linguistic capabilities (Figure 1). 


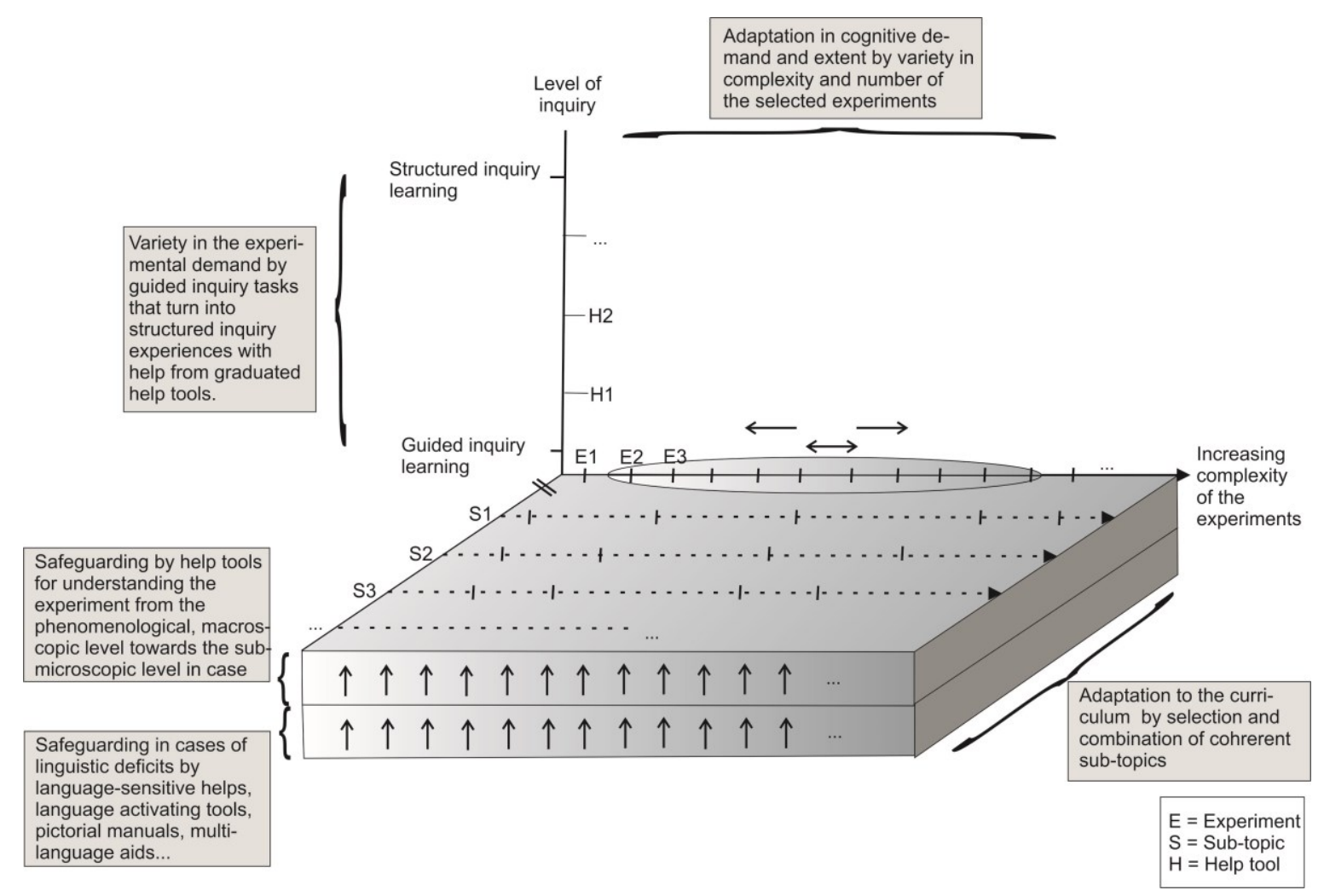

Figure 1. Model of differentiated learning environments in SLs. The figure shows the structure of highly differentiating teaching and learning environments, which are developed and tested for use in SL environments within the present project. Each of the learning environments consists of three to five sub-topics, which each are composed of four to six individual experiments. The various experiments in each sub-theme vary in their complexity and depth of cognitive demand with respect to the learning group. This allows for a flexible adaptation of the learning environment to match all students' personal interests, prior-knowledge, and cognitive and problem-solving capabilities. Graduated aids allow for different levels of inquiry from guided to structured inquiry learning. Additional aids support understanding and help reducing linguistic deficits.

The aim of differentiated instruction is to enable all students to solve each of the tasks on their own. All of the experimental tasks are developed with regard to a student-centered, inquiry-based pedagogy [27]. Students work in groups of two or three in a cooperative learning process. Garner et al. [24] has suggested the SL as a place where productive failures can be experienced to later be corrected by better solutions. Thus, experimental instructions are given for all levels promoting open or guided inquiry learning. However graduated learning aids are implemented to allow low-achieving students to master a structured inquiry learning process [28]. Different tools are available to support students at different performance levels. The learning aids are given at the phenomenological-descriptive, the verbalexplanatory, and the sub-microscopic or formal-representational levels. Aside from this, learning aids focus on content and on the process of inquiry. Additional aids are also provided when dealing with linguistic heterogeneity among the students. Each set of laboratory instructions also contains a set of language-sensitive tools. Examples of these include language-activating tools, pictorial instructions, and multilingual learning aids (word lists, word fields, etc.). 


\subsection{Structuring the Differentiated SL-Modules under Consideration of an Advance Organizer}

Teaching and learning environments for lower secondary school chemistry classes and extracurricular educational institutions, such as tutoring clubs, have been developed in the project Chemistry, Environment, Sustainability: Non-formal Learning Environments for all Students. This project uses an out-of-school laboratory visit as the central pivot point. The current project employs the cooperation of four SLs located at four different German universities: the Universities of Bremen, Erlangen-Nuremberg, of the Saarland at Saarbrücken, and the University of Education Karlsruhe. All the partners were selected by the project initiator, the University of Bremen, since all partners maintain well-established SLs and drive in-service chemistry teacher education centers for dissemination of the project outcomes. One partner, the Institute for Science Education of the University of Bremen, is currently developing and piloting the learning environments. These are then transferred to and adopted by all of the other partners. The aim is to have each partner generate a minimum of 1500 students who have visited the different learning environments from each of the four SLs within a period of three years.

The non-formal learning experience is meant to be prepared in school by teachers before their classes visit the out-of-school learning environment. All of the necessary laboratory instructions and supplementary materials, e.g., information for how to behave at the laboratory, are provided to the teacher by the SL staff. A manual explaining the background and the range of possibilities for the student laboratory visit is also given to the teacher. It contains copies of the laboratory instructions and suggestions for further reading. This enables the teacher to acquire an overview of the topic and to prepare the students for the activities to be performed in the SL. The SL visit takes generally three hours. If the teachers want to extend the time, additional activities are provided. Each session starts with a brief preparation phase with the help of an advance organizer. An advance organizer is a graphical tool to provide the learner orientation about the learning process and any corresponding activities. Ausubel [29] describes an advance organizer as an introductory material to provide well-structured visualizations, to organize the cognitive learning and to enable students to deal with high complexity of teaching concepts.

The advance organizer used to orient the students for the coming tasks links sustainability knowledge and skills to questions about career orientation (see Figure 2). Stuckey at al. describe career orientation as one essential component of relevant science education [30]. Since we know that especially lower achieving students have deficits in career orientation when it comes to science and sustainability related professions [26] the advance organizer is used here to help contextualizing the learning of chemistry by corresponding career options. Examples for potential future jobs and examples of products directly connected to the learning environment topic are used to provide orientation for the experimental tasks within the learning environment. Luiten et al. [31] and Fraser et al. [32] provide evidence for the effectiveness of an advance organizer for supporting learning in science. The advance organizer attempts to raise students' motivation for the practical work in the SL and can increase students' interest levels in general [32]. The use of an advance organizer can also help activate prior concepts, consolidate new knowledge, and allow better orientation while conducting the experimental stage. 


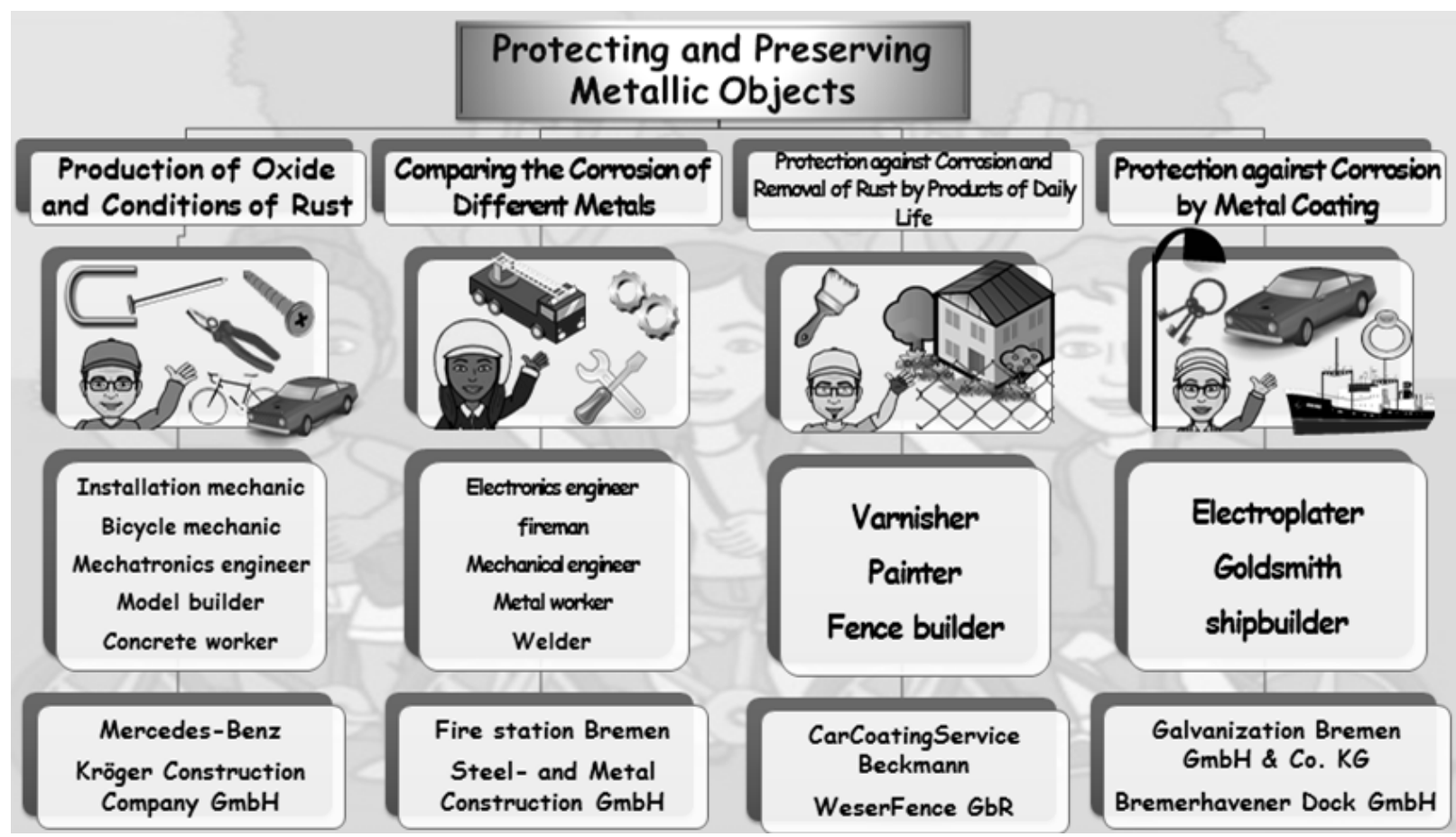

Figure 2. Advance organizer for the module Protecting and Preserving Metal Objects.

All topics for the different modules have been chosen to meet the essential competencies and contents addressed by the aspect of sustainability. The target groups are secondary school science and chemistry classes in grades 5-10 (age range 10-16). A total of four modules have been developed to date. Each of the modules offer a set of roughly 20 experiments of which students and teachers can make a selection of. Such intense learning experience in school is generally not possible because of issues of time for preparation, equipment, and infrastructure. All chemistry and sustainability learning aspects have been embedded into contexts taken from everyday-life issues, the environment or technology. The focal points of the various modules cover the properties of substances, various separation methods, electrochemistry, organic chemistry and sustainable technologies. Each module also narrows in on a specific aspect of sustainability. The topics include water quality and water treatment, protecting and preserving objects, modern technologies in the context of sustainable mobility, and the modern synthesis of sustainable materials. Creative approaches, e.g., experimental instructions in the form of comic books, Internet forums, blogs, and on-line news reports also support students' motivation and help lower barriers in experimental tasks, which are often caused by linguistic deficits among many of the target group students. According to Tatalovic [33] comics and related approaches to science tasks have high potential as lesson starters to revive existing scientific vocabulary, preconceptions and misconceptions. Such creative media can motivate students to ask questions and they can help gauge students' understanding of science topics [33].

\section{One Example in Practice}

\subsection{Protecting Metal Objects as a Student-Oriented Issue Related to Sustainability}

Various devices in daily life are made of metals. Aside from plastic, glass and fiber composites, metal is a material which can be used for a variety of purposes-bicycles, kitchenware, and the 
manufacture of ships, airplanes, automobiles, and various machines. Iron reinforcing bars are used in the construction of buildings. Aluminum is used in manufacturing cars and planes. However, many metal objects are also negatively affected by corrosion. Corrosion is degradation that results from the interaction of metals with aspects of the environment such as air, water, chemicals and pollutants. Contact of metal objects with a corrosive environment containing oxygen, carbon dioxide, water, and a variety of further substances is unavoidable if the metal objects are unprotected. Metal corrosion causes significant economic and environmental damage every year, e.g., by corrosion of steel bridges, in ferroconcrete, on cars, ships, or industrial plants. Protection against corrosion is an important sustainability issue since damages will cause economic loss and might contribute to environmental or safety issues. Protecting items against corrosion will also save natural resources, e.g., minerals, and reduce energy consumption [34].

The corrosion resistance of any metal depends on the environment to which it is exposed. Iron and steel are the most versatile, least expensive, and most widely used materials. They are unequalled in their range of mechanical and physical properties, which can be enhanced by alloying and heat treatment. Their primary disadvantage is that they have poor corrosion resistance in even relatively mild environments, unlike stainless steel. Corrosion reduces the load-carrying capacity of a component either by reducing its size or by pitting its surface. Any technique that acts as a protective barrier or reduces or eliminates corrosion will extend the lifetime of an item.

Meanwhile, current legislation and insurance clauses demand the implementation of technical measures to protect metal objects. Many different methods of protecting metals against corrosion are based on either covering the surface of the metal to shut out air and water, or on applying electrochemistry (e.g., galvanization and sacrificial anode protection). Understanding the importance of corrosion protection requires learning about how chemical developments are interwoven with ecological, economic and societal impacts and how the decisions resulting from this issue will impact life on the individual, societal, and economic level. Because of the everyday and technical importance of corrosion and the character of the topic in its direct impact on students' lives, corrosion is a relevant topic for sustainability-oriented chemistry education.

\subsection{The Module Protecting and Preserving Metallic Objects}

The SL learning environment Protecting and Preserving Metal Objects targets grade 7-8 students (age range 13-15) in lower secondary science education. The curriculum-relevant contents are oxidation, reduction and redox reactions of metals, the sustainable use of raw materials as an economic resource, and the existing technologies for corrosion protection. The learning environment includes an offer of twenty-one experiments divided into four sub-topics (Table 1). The topics are selected based on their importance for sustainability and relevance to the school curricula. Each experiment usually takes between 15 and 25 min.

The experiments in each of the sub-topics differ in the degree of cognitive demand and complexity. In sub-topic 1 the learners compare the potential corrosion rates of iron in a dishwasher with the corrosion of iron during manual washing. They investigate that some knives made of iron corrode in the dishwasher under certain conditions. In another experiment, the students form iron oxide by heating iron and they explore how heat cushions work based on iron oxidation. In this context, the 
students can recognize the development and the conditions accompanying rusting, e.g., the influence of salt, oxygen and water. The core of sub-topic 2 is the reaction of metals in metal salt solutions. Learners link the reactions of zinc, iron and copper by acid to the corrosion resistance of a barbecue grill. They inquire into the reaction of different metals with water vapor and explain why copper is suitable for kitchenware. The experiments in sub-topic 3 show learners which products from everyday life can be used for protection against rust. Olive oil, nail polish, permanent markers and cola and lemonade are compared and their protection potential against corrosion is discussed. In sub-topic 4 the corrosion of a freshly-opened can of fruits is compared with the corrosion of a can which was opened several hours or days before. Learners also compare the reaction behavior of pure iron to that of iron in contact with zinc and copper, thereby learning about the role of electrochemistry in corrosion protection. Table 2 shows an overview of the different activities.

Table 1. Sub-topics of the module Protecting and Preserving Metal Objects.

\begin{tabular}{lc}
\hline & Subtopic \\
\hline 1 & Formation of oxides and conditions of rust \\
2 & Comparing the corrosion of different metals \\
3 & Protection against corrosion and removal of rust from everyday products \\
4 & Protecting metals with coatings \\
\hline
\end{tabular}

The differentiated instructions of this non-formal learning environment contain graduated learning tools which are illustrated in the instructions by different symbols. The tools are available to support students at different performance levels and allow all students, both low- and high-achievers, to participate in the inquiry process. Creative approaches using these instructions, e.g., comics, blogs, news, messages on Instagram, WhatsApp and Facebook, are selected according to the age range of the pupils and their social environments and everyday lives.

Table 2. Sub-topics and experiments (E) for the module Protecting and Preserving Metal Objects.

\begin{tabular}{|c|c|c|c|c|c|}
\hline Sub-Topic & Experiment & $\begin{array}{c}\text { Creative } \\
\text { Approach }\end{array}$ & Sub-Topic & Experiment & $\begin{array}{l}\text { Creative } \\
\text { Approach }\end{array}$ \\
\hline \multirow{6}{*}{$\begin{array}{c}\text { 1: } \\
\text { Production } \\
\text { of Oxides } \\
\text { and } \\
\text { Conditions } \\
\text { of Rusting }\end{array}$} & $\begin{array}{l}\text { E1: The behavior of } \\
\text { knives } \\
\text { in the dishwasher }\end{array}$ & Comic & \multirow{6}{*}{$\begin{array}{c}\text { 2: } \\
\text { Comparing } \\
\text { Corrosion } \\
\text { of } \\
\text { Different } \\
\text { Metals }\end{array}$} & $\begin{array}{c}\text { E1: Base and } \\
\text { precious metals }\end{array}$ & $\begin{array}{l}\text { Game of } \\
\text { dominoes }\end{array}$ \\
\hline & E2: The formation of rust & Comic & & $\begin{array}{l}\text { E2: The behavior of } \\
\text { local elements }\end{array}$ & $\begin{array}{l}\text { Notepad, } \\
\text { puzzle }\end{array}$ \\
\hline & $\begin{array}{c}\text { E3: Formation of } \\
\text { copper oxide }\end{array}$ & Cartoon & & $\begin{array}{c}\text { E3: Reactions of metals } \\
\text { with acids }\end{array}$ & Cartoon \\
\hline & $\begin{array}{l}\text { E4: Formation of copper } \\
\text { carbonate }\end{array}$ & Comic & & $\begin{array}{c}\text { E4: Reaction of metals } \\
\text { with oxygen }\end{array}$ & Newspaper \\
\hline & $\begin{array}{l}\text { E5: Rusting in a } \\
\text { heating cushion }\end{array}$ & $\begin{array}{c}\text { Photo, comic, } \\
\text { notepad }\end{array}$ & & \multirow{2}{*}{$\begin{array}{l}\text { E5: Reaction of zinc, iron and } \\
\text { copper with water vapor }\end{array}$} & \multirow{2}{*}{ Letter } \\
\hline & E6: Conditions of rusting & $\begin{array}{l}\text { Cartoon, } \\
\text { recipe }\end{array}$ & & & \\
\hline
\end{tabular}


Table 2. Cont.

\begin{tabular}{|c|c|c|c|c|c|}
\hline Sub-Topic & Experiment & $\begin{array}{c}\text { Creative } \\
\text { Approach } \\
\end{array}$ & Sub-Topic & Experiment & $\begin{array}{c}\text { Creative } \\
\text { Approach }\end{array}$ \\
\hline \multirow{7}{*}{$\begin{array}{c}\text { 3: } \\
\text { Protection } \\
\text { against } \\
\text { Corrosion } \\
\text { and } \\
\text { Removal of } \\
\text { Rust from } \\
\text { Everyday } \\
\text { Products }\end{array}$} & $\begin{array}{l}\text { E1: The use of everyday } \\
\text { products for protection } \\
\text { against rusting }\end{array}$ & Online forum & \multirow{7}{*}{$\begin{array}{c}\text { 4: } \\
\text { Protection } \\
\text { against } \\
\text { Corrosion } \\
\text { by Metal } \\
\text { Coating }\end{array}$} & E1: Corrosion of a can & $\begin{array}{l}\text { Cartoon, } \\
\text { photos }\end{array}$ \\
\hline & $\begin{array}{l}\text { E2: Reaction of rust in } \\
\text { cola and lemonade }\end{array}$ & Comic & & $\begin{array}{l}\text { E2: The behavior } \\
\text { of copper alloys }\end{array}$ & $\begin{array}{l}\text { Online } \\
\text { forum }\end{array}$ \\
\hline & \multirow{5}{*}{$\begin{array}{l}\text { E3: Protecting gutters } \\
\text { and down spouts by zinc }\end{array}$} & \multirow{5}{*}{ Comic } & & E3: Corrosion of aluminum & $\begin{array}{c}\text { Newspaper, } \\
\text { puzzle }\end{array}$ \\
\hline & & & & E4: Formation of brass & $\begin{array}{c}\text { Book entry, } \\
\text { photos }\end{array}$ \\
\hline & & & & $\begin{array}{l}\text { E5: Protecting corrosion by } \\
\text { sacrificial anodes }\end{array}$ & $\begin{array}{l}\text { Online } \\
\text { forum }\end{array}$ \\
\hline & & & & E6: Zinc alloys & Comic \\
\hline & & & & E7: Anodizing aluminum & Letter \\
\hline
\end{tabular}

\section{Development and Evaluation}

\subsection{Method and Sample}

The development of the learning environments follows a cyclical process of design, testing, evaluation and optimization. Questionnaires for learners are used in each implementation phase. Student feedback is used to optimize the learning environments. This data is supplemented by observation protocols from the laboratory sessions. The student questionnaire focuses on the learner's perception of the topics, the instruction materials, the selected pedagogy, and the language-sensitive design. It includes a total of 10 items with four-point Likert scales and two open-ended questions. Quantitative data was evaluated with the help of descriptive statistics by graphical representations and comparisons of the data in different chart formats. This data interpretation is triangulated by using answers from the open questions and from teacher observations and the observation protocols to construct meaning.

Learning environments for six different topics (see Table 3) are currently under development in the project that later will be implemented in all the four SLs at the different partner universities. The first four topics have been underway since April of 2015 at the University of Bremen in northern Germany. Two more learning environments are currently under development and will be implemented by autumn 2015. So far, seven classes with a total of 141 students have visited the differentiated, non-formal learning environments. These pupils came from an urban comprehensive school with a particularly high rate of students with migration backgrounds (roughly two-thirds) in the student population. The following percentage responses of the questionnaire represent the 141 students who experienced one of the differentiated non-formal learning environments so far. Research in this project is still in an early phase, but trends have already been identified. 
Table 3. Overview of the differentiated non-formal learning environments.

\begin{tabular}{|c|c|c|}
\hline Grade & Module & Aspect of Sustainability \\
\hline 5 th $/ 6$ th & $\begin{array}{l}\text { Discovering old crops for chemical } \\
\text { and pharmaceutical industries }\end{array}$ & $\begin{array}{l}\text { Stewardship of resources and the use of renewable } \\
\text { raw materials }\end{array}$ \\
\hline 5 th $/ 6$ th & Exploring and improving water quality & Purification and efficient use of limited resources \\
\hline 7 th/8th & Protecting and preserving metallic objects & The reduced need to continually use of natural resources \\
\hline 7 th/8th & $\begin{array}{l}\text { The contribution of chemistry } \\
\text { to sustainable mobility }\end{array}$ & $\begin{array}{l}\text { Renewable energy sources to protect resources } \\
\text { and limit climate change; innovative materials } \\
\text { for lightweight engineering }\end{array}$ \\
\hline 9 th/10th & Energy storage for energy change & $\begin{array}{c}\text { Sustainable energy supply, new technologies for energy } \\
\text { storage, realizing greater energy efficiency }\end{array}$ \\
\hline 9 th/10th & Bioplastics for a more sustainable future & $\begin{array}{l}\text { The properties, synthesis, application, } \\
\text { recycling and of different bioplastics }\end{array}$ \\
\hline
\end{tabular}

\subsection{Preliminary Results}

Almost all students (over 95\%) indicated that they perceived the above issues to be at least partially personally interesting to them. More than $90 \%$ of the participants agreed mainly or completely to a statement corresponding to this (Figure 3). The learners admitted that the instructions of the experiments provoked their situational interest. Connecting the experimental instructions with Internet forum entries was viewed as motivating by a large part of the students. Both of these statements met high levels of agreement (about 60\%), with another group of about $30 \%$ agreeing partially. The vast majority of the students responded with at least partial agreement that they had had fun during the experiments (about 90\%) and that the experimental tasks had encouraged them to engage more in chemistry learning (roughly $80 \%$ ). The use of comics for describing the instructions was also considered particularly motivating (about $80 \%$ ). Students gave also at least partially positive feedback concerning the language-sensitive design (about 95\%) and the differentiation of the learning environments. Overall, the students indicated that the experimental instructions were comprehensible in terms of wording, objectives, and help tools. Between $70 \%$ and $80 \%$ fully agreed to this statement and roughly $20 \%$ added their partial agreement. Only a small percentage of the students had difficulties in conducting the experiments with the aid of the different tools. Answers to the openended questions and teacher's feedback support the indications of very positive overall feedback to the learning experience. Both students and teachers, which shared their feedback orally in conversations with the staff of the student laboratory, thought that the visit to the SL had contributed to raising the pupils' motivation towards science learning, as well as increasing the overall learning effects with respect to social skills. The teachers saw motivational potential in the sustainability relevant topics. They also valued the vocational orientation and the creative design of the instructions, particularly with regard to the everyday lives of their students. Although the topics in this learning environment sound a bit male-oriented because of their mainly technological nature, so far no differences in the perception of the topics between boys and girls was found or described by the teachers. These initial results indicate that such learning environments in their differentiated form, including the various combinations of innovative pedagogical tools, have the potential to promote higher levels of student interest and increase learner motivation. These initial findings parallel the experiences and feedback 
collected in other previously implemented learning environments based on chemistry learning in sustainability contexts [10,35].

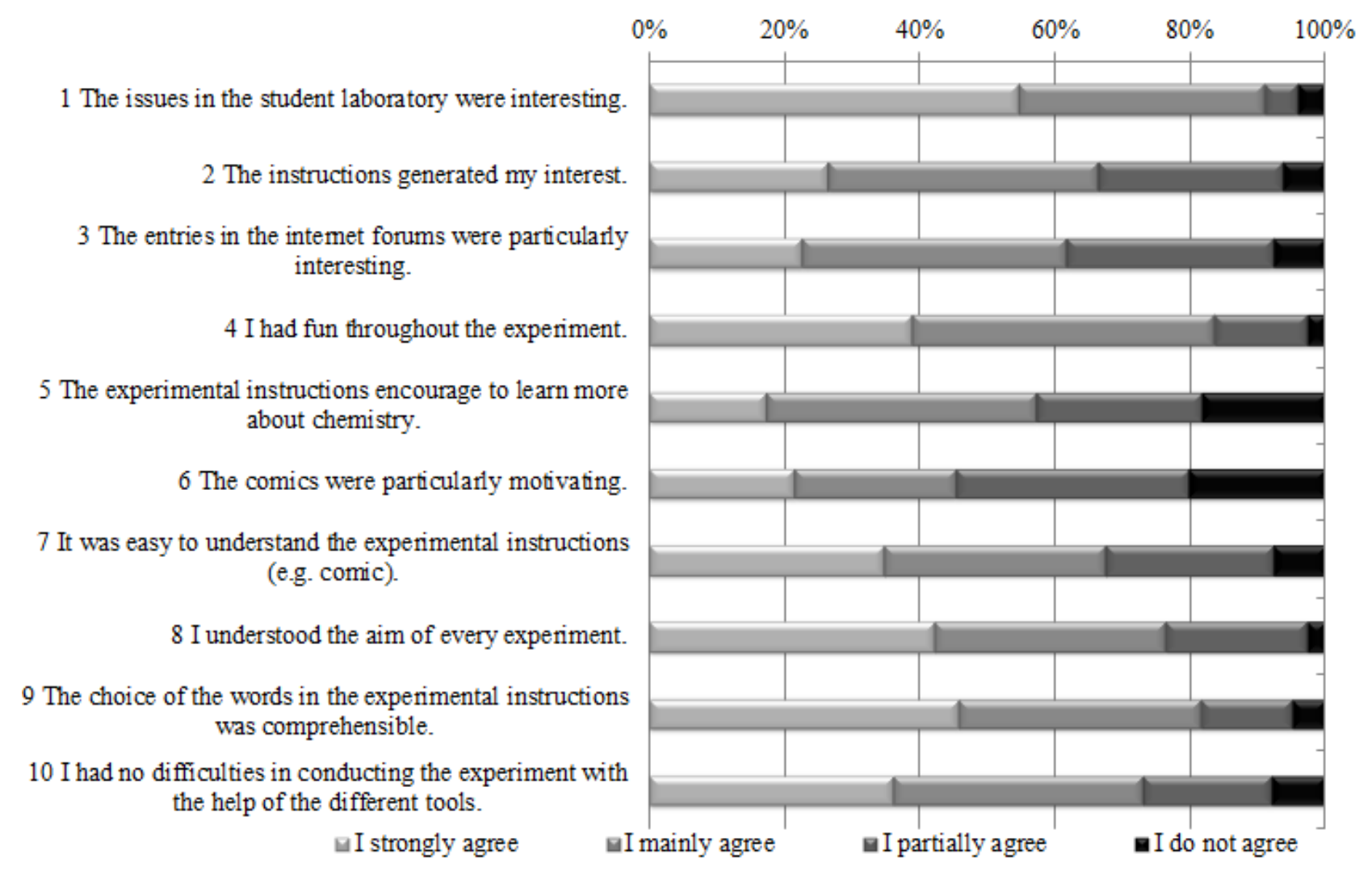

Figure 3. Results of the questionnaire-based study with a total of 10 items.

\section{Conclusions}

Orion and Hofstein [36] have stated that a more positive student attitude towards learning science can be fostered with the help of non-formal learning experiences. They have suggested flexible nonformal learning environments as a supplement to the school curriculum to adapt the situation to the students' skills and needs. When the learning environment is well-adapted, even lower-achieving students can become highly motivated and profit from the practical work offered by SLs [37]. Within the SL in the current project described here, the students were exposed to contextualized learning environments with a set of new and creative pedagogical innovations. These innovations have the goal of opening science learning to all types of learners with the support of multi-differentiated learning environments which take the learners' different personal interests, varying cognitive capabilities, and heterogeneous linguistic skills into account. This project wishes to promote student motivation and science learning, but also to provide improved learning opportunities on topics relevant to education for sustainability to learners from educationally disadvantaged backgrounds [24].

For the purposes of the current project, a multi-dimensional differentiation model was developed to make the non-formal SL a valuable learning experience for all students, despite their different interests and capabilities. The overall student and teacher feedback was very positive. The different topics presented by the learning environments, as well as the pedagogies applied in them, were seen as interesting, relevant, and feasible by the participants. Connecting science learning to authentic issues 
within the sustainability debate proved motivating and meaningful to the learners. Embedding the topic into a non-formal environment structured by an advance organizer was of great help. The case study presented here indicates that the model of differentiation has great potential for feasibly structuring non-formal laboratory learning environments in terms of suitability for all learners. This also includes low-achieving students from disadvantaged educational backgrounds. Feedback from the students and teachers provided initial indications that approaching science learning through sustainability-relevant topics using the new model of differentiation is a positive approach. This learning model can help make learning experiences in SLs more manifest and to allow larger numbers of students to find their own approach to science learning.

Up until now, the research has not focused specifically on learning achievement and the development of sustainability skills. Subsequent research is now focusing on changes in learners' attitudes towards science learning, sustainability, and vocational orientation. It takes pupils' privileged and disadvantaged educational backgrounds into account. In doing so, a special focus will be put on differences between students with varying educational biographies, achievement levels, and attitudes towards science education. This project is also broad enough in scope to examine and localize the most suitable degree of differentiation necessary for non-formal learning to support learning about chemistry-related issues in sustainability and sustainable development. This will also be a part of further research after curriculum development is finished.

\section{Acknowledgments}

We gratefully acknowledge the generous funding of this project by the Deutsche Bundesstiftung Umwelt (DBU).

\section{Author Contributions}

Authors Ingo Eilks, Antje Siol and Silvija Markic jointly designed and are leading the project at the University of Bremen, Germany, and its corresponding pedagogy. Refining the pedagogy and developing the example was supported by authors Fiona Affeldt and Katharina Weitz. Collection and analysis of evaluation data was performed Fiona Affeldt and Katharina Weitz. All authors contributed to the writing of the manuscript. All authors read and approved the final manuscript.

\section{Conflicts of Interest}

The authors declare no conflict of interest.

\section{References}

1. Stocklmeyer, S.; Rennie, L.; Gilbert, J. The roles of the formal and informal sectors in the provision of effective science education. Stud. Sci. Educ. 2010, 46, 1-44.

2. Hempelmann, R. Schülerlabors and sustainability. In Science Education Research and Education for Sustainable Development; Eilks, I., Markic, S., Ralle, B., Eds.; Shaker: Aachen, Germany, 2014; pp. 189-198. 
3. Garner, N.; Hayes, S.M.; Eilks, I. Linking formal and non-formal learning in science educationA reflection from two cases in Ireland and Germany. Sisyphus J. Educ. 2014, 2, 10-31.

4. Haupt, O.J.; Domjahn, J.; Martin, U.; Skiebe-Corrette, P.; Vorst, S.; Zehren, W.; Hempelmann, R. Schülerlabor-Begriffsschärfung und Kategorisierung (Schülerlabor-Clarifying the term and categorization). Math. Naturwiss. Unterr. 2013, 66, 324-330. (In German)

5. Guderian, P.; Priemer, B. Interessenförderung durch Schülerlaborbesuche-Eine Zusammenfassung der Forschung in Deutschland (Promoting interest by Schülerlabor visits. A review of research in Germany). Phys. Did. Sch. Hochsch. 2008, 7, 27-36.

6. Itzek-Greulich, H.; Flunger, B.; Vollmer, C.; Nagengast, B.; Rehm, M.; Trautwein, U. The impact of a science center outreach lab workshop on german 9th graders' achievement in science. In Science Education Research for Evidence-Based Teaching and Coherence in Learning, Proceedings of the 10th Conference of the European Science Education Research Association, Nicosia, Cyprus, 2-7 September 2013; ESERA, Ed.; European Science Education Research Association: Nicosia, Cyprus, 2014; pp. 97-106.

7. Zehren, W.; Neber, H.; Hempelmann, R. Forschendes Lernen im Schülerlabor (Inquiry learning in the Schülerlabor). Math. Naturwiss. Unterr. 2013, 66, 416-423.

8. OECD. Higher Education and Adult Learning-Recognition of Non-Formal and Informal Learning. Available online: http://www.oecd.org/edu/skills-beyond-school/recognitionofnonformalandinformallearning-home.htm (accessed on 7 June 2015).

9. Coll, R.K.; Gilbert, J.K.; Pilot, A.; Streller, S. How to benefit from the informal and interdisciplinary dimension of chemistry in teaching? In Teaching Chemistry-A Studybook; Eilks, I., Hofstein, A., Eds.; Sense: Rotterdam, The Netherlands, 2012.

10. Garner, N.; Siol, A.; Eilks, I. The potential of non-formal laboratory environments for innovating the chemistry curriculum and promoting secondary school level students education for sustainability. Sustainability 2015, 7, 1798-1818.

11. World Commission on Environment and Development (WCED). Report of the World Commission on Environment and Development: Our Common Future. 1987. Available online: http://www.un-documents.net/our-common-future.pdf (accessed on 4 June 2015).

12. Sjöström, J.; Rauch, F.; Eilks, I. Chemistry education for sustainability. In Relevant Chemistry Education-From Theory to Practice; Eilks, I., Hofstein, A., Eds.; Sense: Rotterdam, The Netherlands, 2015; pp. 163-184.

13. UNECD. United Nations Conference on Environment \& Development Rio de Janerio, Brazil, 3-14 June 1992. Available online: https://sustainabledevelopment.un.org/content/documents/ Agenda21.pdf (accessed on 5 June 2015).

14. Bradley, J.D. Chemistry education for development. 2005. Available online: http://www.iupac.org/publications/cei/vol6/03_Bradley.pdf (accessed on 5 June 2015).

15. Leadbitter, J. PVC and sustainability. Prog. Polym. Sci. 2002, 27, 2198-2200.

16. Bodner, G.M. Green chemistry and sustainability education in the U.S. In Science Education Research and Education for Sustainable Development; Eilks, I., Markic, S., Ralle, B., Eds.; Shaker Verlag: Aachen, Germany, 2014; pp. 113-122.

17. Anastas, P.T.; Warner C.J. Green Chemistry: Theory Practice; Oxford University Press: Oxford, UK, 1998; p. 8 . 
18. Centi, G.; Perathoner, S. From green to sustainable chemistry. In Sustainable Industrial Processes; Cavani, F., Centi, G., Perathoner, S., Trifiro, F., Eds.; Wiley-VCH: Weinheim, Germany, 2009; pp. $1-72$.

19. Burmeister, M.; Rauch, F.; Eilks, I. Education for Sustainable Development (ESD) and secondary chemistry education. Chem. Educ. Res. Pract. 2012, 13, 59-68.

20. Burmeister, M.; Schmidt-Jacob, S.; Eilks, I. German Chemistry Teachers' Understanding of Sustainability and Education for Sustainable Development-An Interview Case Study. Chem. Educ. Res. Pract. 2013, 14, 169-176.

21. Burmeister, M.; Eilks, I. An understanding of sustainability and education for sustainable development among German student teachers and trainee teachers of chemistry. Sci. Educ. Int. 2013, 24, 167-194.

22. Van Driel, J.H.; Bulte, A.M.; Verloop, N. The conceptions of chemistry teachers about teaching and learning in the context of curriculum innovation. Int. J. Sci. Educ. 2005, 27, 303-322.

23. Garner, N.; de Lourdes Lischke, M.; Siol, A.; Eilks, I. Learning about Chemistry's Contributions to Sustainable Development in an Non-Formal Laboratory Context for Secondary Level Students. In Handbook of Research on Pedagogical Innovations for Sustainable Development; Thomas, K.D., Muga, H.E., Eds.; IGI Global: Hershey, PA, USA, 2014; pp. 229-244.

24. Garner, N.; Siol, A.; Huwer, J.; Hempelmann, R.; Eilks, I. Sustainability and chemistry in non-formal student laboratories: A project to support learning about sustainability. In Science Education Research and Education for Sustainable Development; Eilks, I., Markic, S., Ralle, B., Eds.; Shaker: Aachen, Germany, 2014; pp. 199-208.

25. Bloemen, A.: Heyse, K.; Porath, J., Schlömer, T. Die Integration von Nachhaltigkeit und Energiebildung in die berufliche Bildung benachteiligter Jugendlicher (The integration of sustainability and energy education in vocational training of disadvantaged young people). In Integration im Prozess der Internationalisierung; Bick, C., Brandt, G., Eiselt, A., Eds.; BIS-Verlag: Oldenburg, Germany, 2012; pp. 13-24.

26. Michelsen, G.; Grunenberg, H.; Rode, H. Was Bewegt Die Jugend (What the Youth Drives); VAS: Bad Homburg, Germany, 2012.

27. Hofstein, A.; Kipnis, M.; Abrahams, I. How to learn in and from the chemistry laboratory. In Teaching Chemistry - A Studybook; Eilks, I., Hofstein, A., Eds.; Sense: Rotterdam, The Netherlands, 2012; pp. 153-182.

28. Tafoya, E.; Sunal, D.; Knecht, P. Assessing inquiry potential: A tool for curriculum decision makers. School Sci. Math. 1980, 80, 43-48.

29. Ausubel, D.P. The use of an advance organizer in the learning and retention of meaningful verbal material. J. Educ. Psychol. 1960, 51, 267-272.

30. Stuckey, M.; Mamlok-Naaman, R.; Hofstein, A.; Eilks, I. The meaning of "relevance" in science education and its implications for the science curriculum. Stud. Sci. Ed. 2013, 49, 1-34.

31. Luiten, J.; Ames, W.; Ackerson, G. A Meta-analysis of the effects of advance organizers on learning and retention. Am. Educ. Res. J. 1980, 17, 211-218.

32. Fraser, K.; Edwards, J. The effects of training in concept mapping on students' achievement in traditional classroom tests. Res. Sci. Educ. 1985, 15, 158-165. 
33. Tatalovic, M. Science Comics und Cartoons. Science in School. 2010. Available online: http://www.scienceinschool.org/sites/default/files/teaserPdf/issue14_web.pdf (accessed on 5 June 2015).

34. Kaesche, H. Corrosion of Metals: Physicochemical Principles and Current Problems, 1st ed.; Springer: Berlin, Germany, 2003.

35. Salmi, H. Science centres as learning laboratories: Experiences of Heureka, the Finnish Science Centre. Int. J. Technol. Manag. 2003, 25, 460-476.

36. Orion, N.; Hofstein, A. The measurement of students' attitudes towards scientific field trips. Sci. Educ. 1991, 75, 513-523.

37. Mischnick, P., Faustmann, B. The Agnes-Pockels-Schülerlabor-An example on how non-formal laboratories can contribute to education for sustainability. In Science Education Research and Education for Sustainable Development; Eilks, I., Markic, S., Ralle, B., Eds.; Shaker: Aachen, Germany, 2014; pp. 215-218.

(C) 2015 by the authors; licensee MDPI, Basel, Switzerland. This article is an open access article distributed under the terms and conditions of the Creative Commons Attribution license (http://creativecommons.org/licenses/by/4.0/). 